\title{
Memories I Never Had: Fires in the Kangra
}

Deborah Nixon

The reflections in this article have arisen from interviews I conducted with my father and stories told to me about his experience of growing up in India and serving with a Gurkha rifle regiment during the Partition of India in 1947.

The stories told by my father, Leslie Nixon, have echoed through my family for as long as I can remember, so much so that they feel like they have become my own memories. Relics from the British Raj, such as kukris, guns, photos and other memorabilia from that time, were scattered throughout our house. I saw photos of India that fascinated and frightened me: a colourized picture of Gandhi, a naked fakir with balls pinned to his body, a series of action shots of a crowd, a riot and casualties in Lahore, and "an unfortunate [dead] Afridi tribesman” laying on a charpoy with his severed head on his chest. I have seen the story in black-and-white photographs of solemn relatives in dusty towns juxtaposed against portraits of Gurkha soldiers beheading animals as they "blood” their kukris. Hundreds of photographs accompany this story.

Leslie was the product of at least three generations in India. He was born in Agra and schooled in Mussoorie. He served in the Indian army, and he vehemently maintains that he was British, even though some things about the family point to a distant Anglo-Indian connection. There is a reluctance to examine any more "exotic" side to the family, despite the appearance of Leslie himself and his five brothers, two sisters, and adopted Anglo-Indian "brother.” As Buettner (278) notes, race in India was not always constructed along strictly biological lines but was an amalgam of factors including where one was schooled, the way one spoke, and where one worked. Many people tended to identify as “real” British in order to distance themselves from the Anglo-Indian population, who, in the words of an Australian 
ex-Gurkha officer with whom I spoke, were both "an embarrassment to the British and looked down upon by the Indians.” This man also met my grandfather in central India in 1946; he assumed that my grandfather was Anglo-Indian on the basis of his accent, which he described as “Anglo-Banglo,” commenting also that he wasn’t a “dyed-in-the-wool Pom”! I have not relayed those comments to my father.

The Nixon family were a railway family of engine drivers and foremen. The railways in India were a major source of employment for domiciled Europeans and Anglo-Indians, and developed into a society in itself ; according to Bear (534) it was a kind of heterotopia. In this interstitial world, domiciled European children spoke Hindi or Urdu and English, and they played with Indian and Anglo-Indian children despite parental efforts to keep them separated. My father was bilingual (he spoke Urdu and English), unlike his London-born mother. Growing up in a railway family meant that the notion of home was never identified with one place. The family moved around a great deal—indeed, the list of family homes reflects this. When asked where home was, Leslie replied, “Bombay, Bhusawal, Itarsi, Nagpur, Damoh, Poona, Bhopal, Jhansi, Sagar ; there may be more.” Children were also sent to distant boarding schools for nine months of the year from the age of five and returned to where ever the family was based for three months. Leslie went to school at St George's in Mussoorie and even though it was not home it was probably the most fixed place he lived in until the age of 17years old. There was very little in this itinerant upbringing to provide the basis for the development of a sense of emotional attachment to a place called home.

In order to try to understand more about this alien family, I travelled to India and searched for-and found-my great-grandmothers’ and grandmothers’ graves in Bhusawal, a town that was once the busiest railhead in India. My father says he saw Gandhi pass through on a train once. When I arrived in Bhusawal I thought I felt a sense of connection to India that I don’t think my father has ever admitted to, nor allowed himself to feel. As I sat at the 
foot of my grandmother's grave and swept my hand across it, a piece of grey marble came off, so I kept it and later showed my brothers in Adelaide. They said it was like looking at a piece of the moon, because Bhusawal and that ancestral life seemed so distant. But, it was confirming to find evidence that the family had been there and had been part of the community. My grandfather's name was recorded in gold letters on a wooden board that lists all the railway foremen in Bhusawal; he was there for seven years—a long time in one place, for a railway family. He was also the vice president of the Limpus Club, an Anglo-Indian and European social club. In photographs my grandfather is always in the centre, surrounded by staff, family, and children—signifying his position, I suppose. Although formally posed, there is an ease that comes through the image of a man who looked as if he belonged in his world.

Seeing these traces of the family in Bhusawal, I felt a kind of proxy nostalgia for the past, though in a temporal, rather than a physical, sense (Blunt 1). The "place” I had in my mind was a pastiche of elements from stories I had been told by my father, photos of the family, raj revival novels, trips to India, and even the Hindi names we gave our family pets! If, as I have heard it defined, nostalgia is a bittersweet combination of both sadness and longing for a time and place in the past, then my father displays something that is more or less the opposite. For my father, there is very little longing and no desire to return, even for a glimpse of India. It is as if he is afraid he might be swallowed up by it and not be able to escape again. Other repatriated soldiers to whom I have spoken, including two Australians who served with the Gurkhas and an Anglo-Indian Australian citizen who served with the Indian Army, had been back to India at least once in the fifty-five years since they left. The Anglo-Indian Australian was rueful about what happened in Partition; he was sorry that he had identified himself as Anglo-Indian in the first place and had not been able to serve in the British army. 
There was more than just a sense of geographical disconnection at play in Leslie's sense of "home.” Although Caplan discusses this displacement in terms of the Anglo-Indian community, it is just as relevant to the domiciled European community, as it related to thinking always that home was elsewhere (“Colonial and Contemporary Transnationalisms”1). In contrast to this, my mother is the product of three generations in Australia, and she is unequivocal about her identity as an Australian. However, Leslie was not a "marginal man” (Caplan “Children of Colonialism” 8), for, as much as he likes to position himself as neutral, he was an active participant in the process of migration. Coming from this background, how could he, a person who could not name a single place as home and did not feel in his heart that he belonged in India, relate to the uprooting of people from ancestral homes that dated back centuries and cradled their culture, as, say, the Punjab did? In many ways, what Leslie says about India reflects a struggle between his oblique sense of nostalgia and his disdain for the very things that make India the vital and chaotic place it is. He is still suspicious of train travel through India, although he has not been back since 1948. He warned me of the dangers when I went travelling there recently, commenting that “trains haven’t been safe since the British left.” His intransigent attitude toward India belies the burden of memories of Partition: "there were painful incidents—it was so long ago I don't know how to recall some of them. On the other hand, some things are burned into my memory.” Leslie’s stories about the Partition were related to my brothers and sisters and me in vivid detail. His recall of certain traumatic events is very clear and specific. In addition, when he speaks about the indigenous Gurkhas in the regiment he served with, he is both respectful of their bravery and, at times, patronizing about and dismissive of their abilities. He carries enormous guilt about the death of some Muslim women and children who mistook Leslie and his men for Hindu attackers and threw themselves into the village well rather than facing the risk of being raped and murdered by Hindus. Many of them drowned despite 
Leslie's frantic efforts to save them. This story horrified us as children, and my sister Kamala says she can still "see" the women jumping into the well with their babies.

Later, when we were older, he told us of the massacres on trains running into and out of Amritsar. He said he did not see them but heard reports from Gurkhas closer the new border of trains full of dead refugees arriving in the station. In the northern district of Kangra, he had to deal with smaller-scale opportunistic attacks and skirmishes that were frightening and often resulted in fatalities. One such incident involved the point-blank shooting of a young girl on a train he was escorting to Pathankot. He said he lifted her veil to see if she was alive and saw her eyeballs in her lap. Incidents such as these did not, he said, “enamour” him of the Indians.

At times when talking to him about his experiences I have to resist the urge to give him the postcolonial version of events and to tell him what I think of his veiled racism, but I can't. They are his stories, his memories, and they reveal a world and an attitude that has its own value. It was a time when murky boundaries existed between people cast in a drama that involved the unravelling of a paradigm of power and identity as the Raj collapsed into the mayhem of Independence, Partition, migration, and murder.

It may be witnessing this final event that sours his reminiscences of India and which later turned Leslie into an alarmist, an old man easily rattled by the smallest changes in his routine, and a madman on the road. He is an eighty-year-old speed-freak, swearing and chasing people in traffic, and he is never, ever in the wrong. Post-traumatic stress doesn't exist, in his opinion, and yet I think it has troubled him throughout his life. His emotions are polarized between an infuriating aloofness and tears triggered by talking about the Partition or the death of his mother, in his words, "at the hands of an incompetent Indian surgeon.” Several of the terrible incidents he witnessed he was unable to talk about unless loosened up by alcohol. These incidents are also, in his opinion, examples of the duplicity and 
untrustworthiness of Indians, who even killed one another. Of course, the tragedy of Partition was that, inexplicably, neighbours did turn on one another, and atrocities did occur. The violence came as a shock, but it wasn't just a shock to Leslie; even the new governments of India and Pakistan were unprepared for the magnitude of the upheaval.

When I asked him what was unique about his story, he replied that, "unlike an historian who has never seen a bullet fired in anger,” he was there transporting and protecting uprooted people on their way from the villages in Himachal Pradesh to the trains at Pathankot. On their journey they were sniped at, they were skewered in carriages, they were shot at, and this was before they reached the main trains at Amritsar, where the scale of massacres increased horribly. He was twenty-two years old at the time, and he has not changed his story from the first telling.

Leslie’s evocative storytelling has arisen from a practiced adherence to a script that has not been changed or challenged over the years. His voice may be fossilized in a moment, but what that moment reveals is of value. There is a lot of sadness about Partition, and there is still incredulity about the level of violence. It was a seminal reason for most Anglo-Indians who made the decision to leave India. Talking to him has opened up a world to me that I find fascinating and contradictory, and I have to be very careful about where I take our discussions, as he demands full purchase, as is his right, over the telling of the story. The parts that he does not want to discuss, or which he uses a memory lapse to avoid, constitute telling omissions that add a further layer of complexity to his “voice.” I am interested in what has inflected his story, so I plan to investigate the family history in India further. 


\section{References}

Bear Gbah, Laura. “Miscegenations of Modernity: Constructing Europeon respectability and race in the Indian railway colony, 1857-1931.” Women’s History Review 3.4 (1994): 531-48.

Blunt, Alison. "Memory, Identity and Productive Nostalgia: Anglo- Indian home-making.” Who are the Anglo Indians? Ed. A Gilbert. Melbourne: East India Club, 2002. 27 Jul. 2005 <http://home.alphalink.com.au/ agilbert/anglo- 1.html>

Buettner, Elizabeth. “Problematic Spaces, Problematic Races: Defining ‘Europeans’ in late colonial India.” Women’s History Review 9.2 (2000): 277-97.

Caplan, Lionel. “Colonial and Contemporary Transnationalisms: Traversing Anglo-Indian boundaries of the mind.” Paper presented at Transnationalisms. University of Manchester, Department of Social Anthropology, 1997. 20 Jun. 2005 <www.alphalink.com.au/ agilbert/cap0399.html>.

Caplan, Lionel. Children of Colonialism: Anglo-Indians in a Postcolonial World, Oxford: Berg, 2001. 